\title{
ASSOCIATION BETWEEN LINEAR TRAITS OF LEGS AND LONGEVITY OF UKRAINIAN BROWN DAIRY COWS
}

\author{
V. I. Ladyka, L. M. Khmelnychyi ${ }^{1}$, S. L. Khmelnychyi ${ }^{2}$, A. M. Salohub ${ }^{2}$ and V. V. Vechorka ${ }^{2}$ \\ Academician of the National Academy of Sciences of Ukraine, Rector of Sumy National Agrarian University, Ukraine \\ ${ }^{1}$ Head of the department for Breeding and Selection of Animals and Water Bioresources, Sumy National Agrarian \\ University, Ukraine \\ ${ }^{2}$ Department of breeding and selection of animals and aquatic bioresources, Sumy National Agrarian University, Ukraine \\ Corresponding Author's E-mail: tanya_goncharova@meta.ua; khmelnychy@ukr.net
}

\begin{abstract}
The influence of conformation traits that characterize mobility, on the life expectancy of Ukrainian brown dairy cows was investigated: rear legs side view (RLS), rear legs rear view (RLRV), hooves angle (FA), and locomotion (L). The dataset consisted of records about productive and linear traits of 489 cows collected from January 1, 2006 to December 31, 2016. Cows with 1-4 scores for RLS were at higher risk of culling than animals with legs close together estimated at 6-9 scores. Cows with optimal development of the trait were used in the herd much longer compared to groups of animals with an estimate of 1-4 scores on 126-831 days and with estimate of 7-9 scores - on 286-505 days. Cows with the highest classification score of the RLRV were lived on 605 days longer compared to animals with 1 score. The dependence of cows longevity on the condition of FA was evidenced by a significant difference between groups of cows with estimates in 7 and 3 scores, which amounted 312 days. Cows with 9 scores for locomotion (L) were retained for 777 days longer as compared to animals with 1 score. The influence of linear traits characterizing extremities development on the life expectancy of cows of Ukrainian brown dairy cattle can be a predictor of longevity that allows indirect cow selection by type.
\end{abstract}

Key words: Ukrainian Brown Dairy, Longevity, Linear Type Traits, Survival Analysis.

https://doi.org/10.36899/JAPS.2020.2.0046

Published online March 02, 2020

\section{INTRODUCTION}

Productive longevity of cows, from the breeding point of view, is quite a complex integrated trait that significantly is determined by genetic factors. However, effective selection on the basis of longevity is complicated due to its low heritability, that according to Pelt et al. (2015), with variability from 0.002 to 0.149 . Stanojević et al. (2016) reporting that values of heritability coefficients of longevity features varied from $0.066 ; 0.061$ and 0.074 as regards to duration of productive life, lifetime productivity and number of lactation, respectively. Estimates of heritability by features of longevity (herd life and longevity) were low (0.11 and 0.09) according to Ghaderi-Zefrehei et al. (2017) and on indicators of survival (0.02-0.05) Krejčová et al. (2008). Besides, to obtain data on longevity of cows is necessary to wait for their withdrawal from the herd.

Considering existence a different level of positive correlation between linear type traits and longevity indicators (Vacek et al. 2006; Zavadilová et al. 2009; Morek-Kopec and Zarnecki 2012; J. du Toit et al. 2012; Kern et al. 2015), a sufficient heritability level of conformation traits (Wiggans et al., 2006; de Haas et al.,
2007) and the ability to score animals in the first lactation, linear type traits can be used as predictors of longevity (Vukasinovic 2002; Esteves et al., 2004); Getu and Misganaw 2015). Numerous scientific studies have proven the longevity of dairy cows as an indicator of health, animal welfare and a sustainable system of milk production (VanRaden and Wiggans 1995; Essl 1998; Sewalem et al., 2005; Zavadilová et al. 2009; Du Toit et al., 2012; Olechnowicz et al., 2016;).

Mobility of cows in the modern technological conditions was a growing problem, since they are constantly located in an aggressive environment on slippery concrete. If the animals were in the pasture, they had to walk long distances. In this aspect, the strength of legs was a certain guarantee of increasing the longevity of dairy cattle in today's intensive milk production conditions (Strapak et al., 2010). Pfeiffer et al. (2014) found correlations between longevity and feet and legs, to be 0.39 .

The aim of this study was to investigate the influence of linear type traits that characterize: angle of rear legs (side view), posture of rear legs (rear view), hoof angle and locomotion, with lifetime of cows of Ukrainian brown dairy breed. 


\section{MATERIALS AND METHODS}

The studies were conducted on livestock of cows of Ukrainian brown dairy breed. This breed was created in Ukraine by crossing aboriginal cattle with brown Swiss breed. In the crossbreeding have been used the sires from different countries (Germany, America, and Austria). The breed was approved as a breeding achievement in 2009 .

The purpose of creating a Ukrainian Brown dairy breed was transformation of Lebedinsky breed combined type of productivity into a specialized breed of dairy type. The new breed had to be distinguished by high milk productivity and a strong conformation type, well adapted to local conditions of feeding and to technological conditions of retention. For this purpose, we conducted a linear classification of the new breed of cows.

Research on the study of relationship between type traits and the longevity were conducted using the data of linear scoring of the first-born cows of Ukrainian Brown dairy breeds of five farms in the Sumy region of Ukraine. The dataset consisted of records about productive and linear traits of 489 cows collected from January 1, 2006 to December 31, 2016. The lifetime of cows calculated as the number of days between date of birth and the date of withdrawal. Linear scoring was performed according to recommendations of the International Committee for Animal Recording (ICAR Recording 2014). Linear type traits were determined only in cows of the first lactation, classified from 15 to 150 days after calving.

In general, the system of linear classification has been used in Ukraine included 18 linear type traits. We were focused attention on the traits that characterize the condition of the limbs. Table 1. The linear traits were scored on a 9-point scale. Each trait with the minimum and maximum deviations, have been represented in absolute units of measurements.

Table 1. Description of linear type traits using nine-point scoring range

\section{Standard linear type traits}

Rear Legs Set (side view)

Rear Legs Rear View (rear view)

Hooves Angle

Locomotion

\begin{tabular}{|c|c|c|c|}
\hline \multicolumn{4}{|c|}{ Score } \\
\hline \multicolumn{2}{|c|}{$\min$} & \multicolumn{2}{|c|}{$\max$} \\
\hline \multicolumn{2}{|c|}{1} & \multicolumn{2}{|c|}{9} \\
\hline Straight & $>158^{\circ}$ & Sickled & $<136^{\circ}$ \\
\hline Extreme toe-out & & Parallel fee & \\
\hline Very low angle & $<25^{\circ}$ & Very steep & $>61^{\circ}$ \\
\hline Severe Abduction & hort Stride & No Abduct & Stride \\
\hline
\end{tabular}

A linear trait is the angle of the pelvic limbs, determined by its bend in degrees. According to our research results, the desired degree of the angle with an estimate of 5 scores varied between $146-148^{\circ}$ and was optimal for cows. Decreasing in the angle of hock joint (elephantiasis) or increase (sickle-shaped) are the disadvantages of this trait of the conformation.

A linear trait the posture of pelvic limbs - very important linear trait of the conformation, which was estimated by their width of the rear view. Cows with parallel legs set were assessed by the highest score. The rapprochement of legs in the hock joints or their curvature significantly reduces the score.

A linear trait - the hoof angle, characterizes the strength of legs and is responsible for their health. This significantly depends on the hardness of hoof horn. The average expression of the state of hoof angle is $45^{\circ}$ with an estimate in 5 score. Than steeper the hoof angle, the higher score characterizing the best development of this trait.

A linear trait - locomotion, was evaluated in the process of movement of the animal. In this case, the direction of movement, linear displacement in space, the intensity of movement, fixation of the support phase and the phase of legs transfer were evaluated, the condition of hooves was taken into account. The score was reduced if the movement was weak and when lameness was present and, on the contrary, solid, confident, steady locomotion, the correct posture of legs, strong hooves and pasterns increase the level of linear assessment. (ICAR Recording, 2014).

From statistical indicators, the average value of linear traits (x) and standard error (S.E.) were studied.

$S . E .=\frac{\sigma}{\sqrt{n}}$

were: $\sigma-$ standard deviation;

$n$ - number of variants.

The coefficient of linear correlation was determined by formula of Pearson :

$$
r_{x y}=\frac{\sum\left(x_{i}-\bar{x}\right) \times\left(y_{i}-\bar{y}\right)}{\sqrt{\sum\left(x_{i}-\bar{x}\right)^{2} \times \sum\left(y_{i}-\bar{y}\right)^{2}}}
$$

Where: $x_{i}-$ value for variable $X$;

$y_{i}-$ value for variable $y$;

$\bar{x}$

- average value for $X$;

$\bar{y}$

- average value for $Y$. 
Statistical data processing was performed using the software in Microsoft Excel using the statistical software package "STATISTICA" version "8.0". The reliability of the statistical values was evaluated by testing the "null hypothesis" with the calculation of standard errors (representativeness) and Student's criteria. The level of reliability (probability of error) was classified by comparison with standard values (levels) generally accepted in statistical practice. The results were considered reliable at the first $(\mathrm{P}<0.05)$, second ( $\mathrm{P}$ $<0.01)$ and third $(\mathrm{P}<0.001)$ thresholds of probability.

In this research 4 type traits, very important for the characteristics of legs: rear legs (side view (RLS), rear legs (rear view (RLRV), foot angle (FA) and locomotion (L) were considered. The development of traits based on visual evaluations expressed in the range of 1 to 9 scores. 5 scores for rear legs (side view (RLS) considered the best variant, that is, 5 scores is characterizing the desired development of this trait.

\section{RESULTS AND DISCUSSION}

The influence of rear legs (side view), rear legs (rear view), foot angle and locomotion on duration of lifetime use in cows of Ukrainian Brown dairy cattle, has been presented in histograms Fig. 1-4.

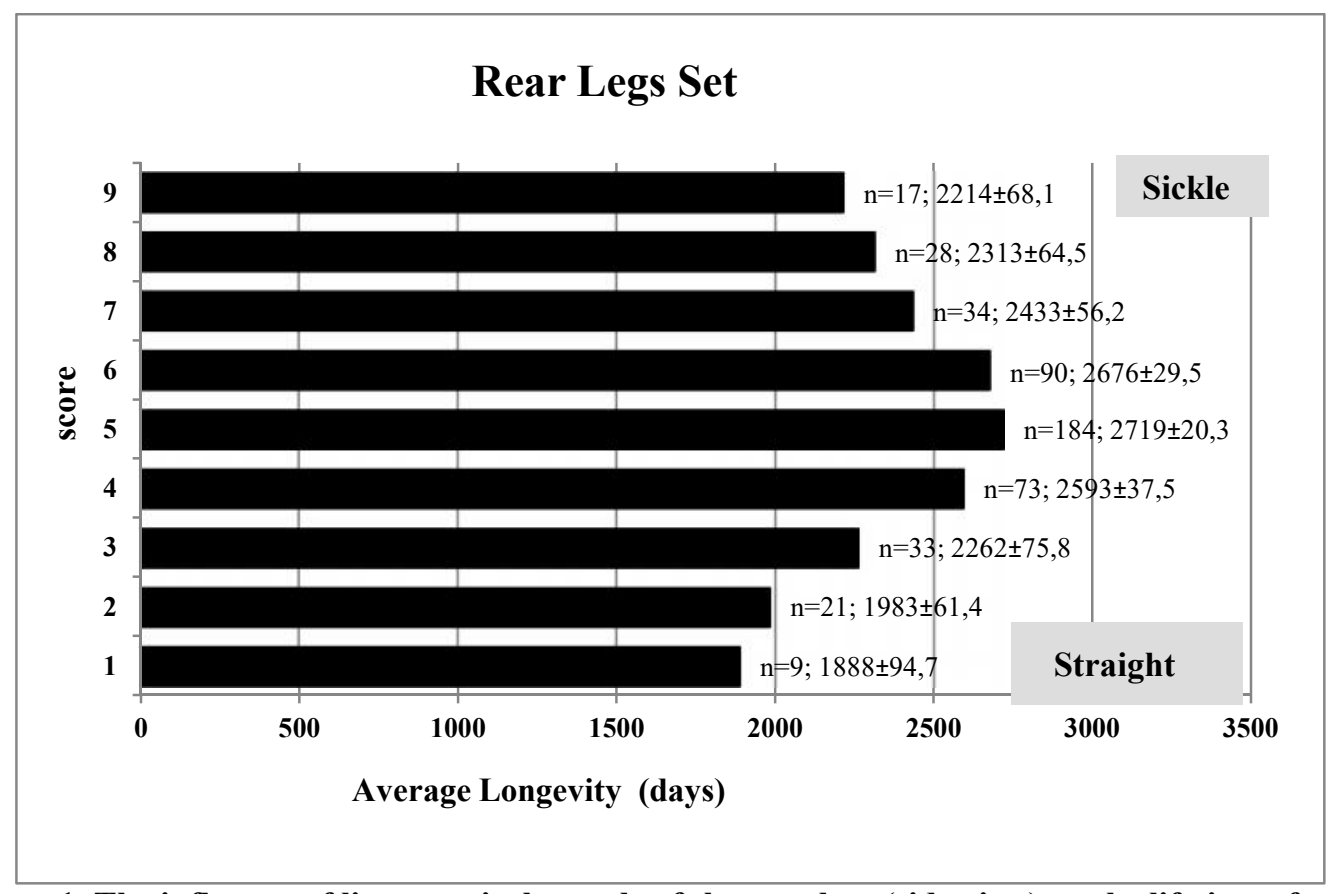

Figure 1. The influence of linear trait the angle of the rear legs (side view) on the lifetime of cows.

According to research results, angle of rear legs significantly affected on the longevity of cows of the studied herd, as evidenced by histogram (Fig. 1).

Experimental cows of Ukrainian brown dairy breed with a 5 score of the assessment of linear trait the hock angle (side view) had the highest lifetime (2719 days). Similar results were obtained by Buenger et al. (2001) at the analysis of survival in dairy cows with supplementary data on type scores and housing systems from a region of Northwest Germany and Caravello et al. (2004) in the analysis of the relationship between type traits and functional survival in US Holstein cattle.

Animals with close posture of legs had the highest risk of culling, which were estimated at 1-4 scores. The lifetime of cows with a score for development of linear trait the hock angle (side view) at 5 scores was longer for 126-831 days than for groups of animals with
1-4 scores $(\mathrm{P}<0.01-0.001)$. Similarly, cows with a 7-9 scores lived longer for 286-505 days $(\mathrm{P}<0.001)$. A similar trend was found in Jovanovac and Raguz (2011) by linear trait of the rear legs (side view) in cows of Croatian Simmental cattle. According to their studies, cows with very straight legs and 2 scores were 1.6 times more likely to be culling than other animals. According to their research cows with a very straight legs and 2 scores had in 1.6 times more likely to be culled than other animals.

The results of researches showed a positive effect of rear legs set (rear view) on the lifetime of animals (Fig. 2). The longest period of time is used in the herd cows with 9 score (2718 days) for rear legs set, but most cows received 7 and 8 scores. With a decrease of score from 6 to 1 , an adequate reduction in the duration of life is observed. Similar results were obtained by 
Vacek et al. (2006), which reported about the lowest duration of lifetime in cows with converged rear legs. Zavadilova and Stipkova (2012), reported about positive genetic correlations between traits of feet and legs, direct longevity and functional longevity (0.19 and 0.14). Cows of Holstein breed in the Czech Republic with an extreme toe-out of rear legs had a lower longevity than cows with straight legs (1998).

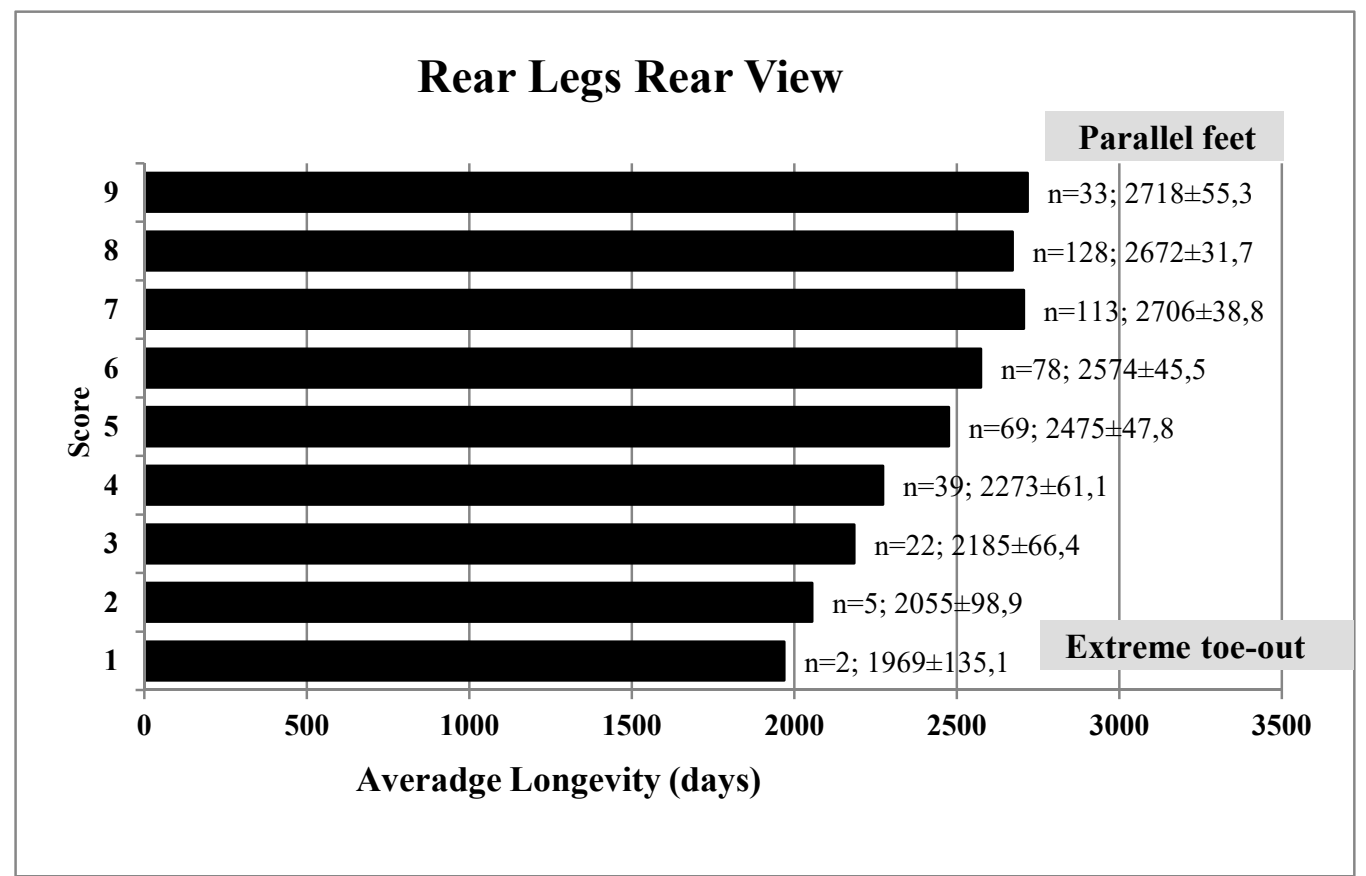

Figure 2. The influence of linear trait of the rear legs (rear view) on the lifetime of cows.

Histogram parameters (Fig. 3) indicated a high influence of foot angle on longevity of cows. Animals with the highest classification lived on 605 days longer than cows with 1 score $(\mathrm{P}<0.001)$.

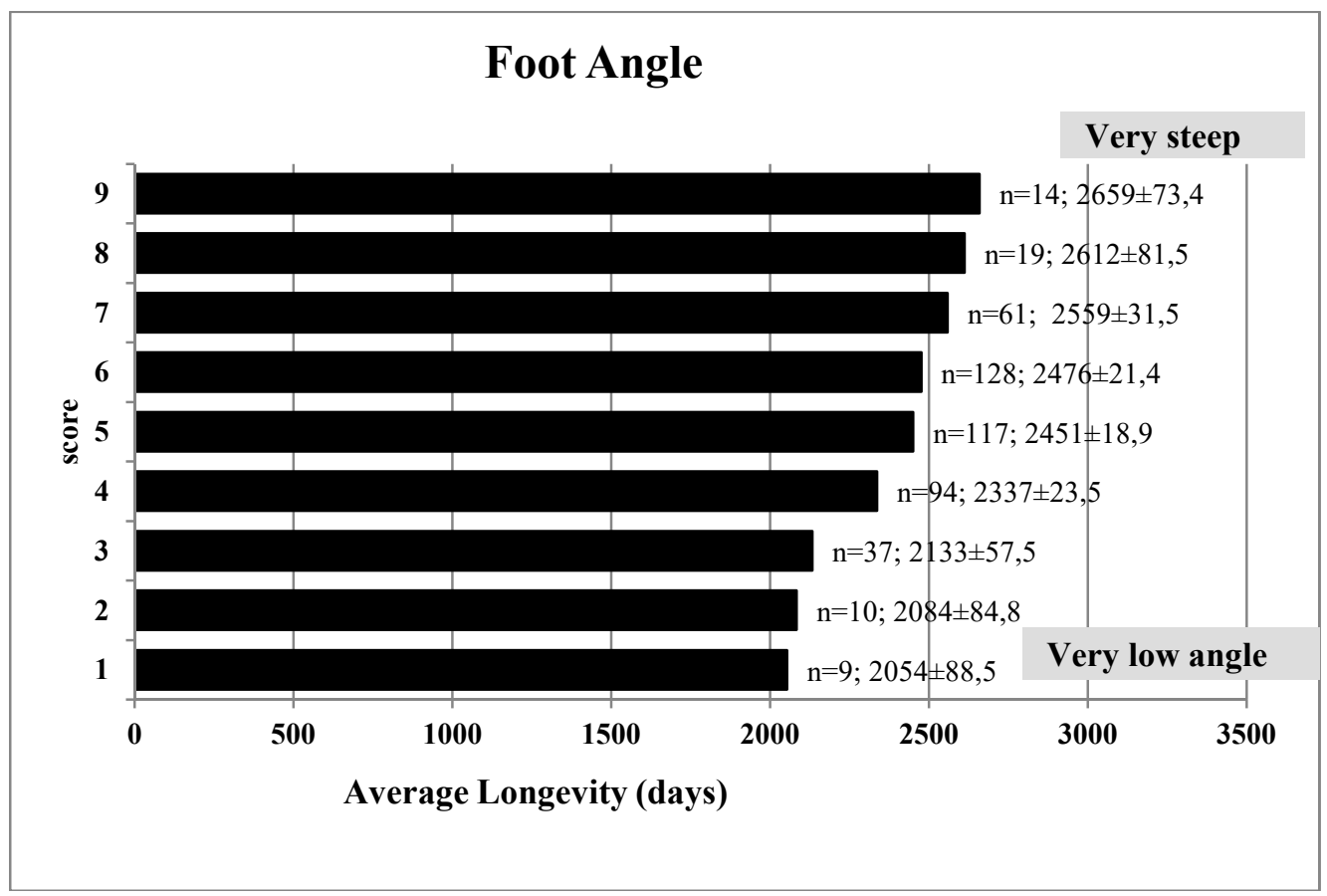

Figure 3. The influence of linear trait of hoof angle on cow lifetime. 
It should be noted that, from all traits that are characterizing the rear legs quality, foot angle with an estimate in 1 score had the least effect on the longevity of cows. Similar results were obtained in the study of complex linear traits in relationship with duration of use Holstein cows of Czech selection Boelling and Pollott (1998), under which influence of foot angle on longevity of cows was minimal. The dependence of longevity cows on the condition of foot angle was evidenced by a significant difference between cows group's with an estimates in 7 and 3 score, which was 312 days at $P$ $<0.001$. Obtained by Kern et al. (2015) negative and moderate genetic correlations in cows of Holstein breed between the foot angle and traits of longevity, which ranged from -0.18 to 0.23 , have a tendency to reduced the lifetime of cows in the herd. According to Samoré et al. (2010) functional longevity had a negative correlation with the posture of rear legs $(-0.56 \pm 0.10)$.
The importance breeding value of estimation for locomotion was confirmed by other studies, due to a corresponding relationship between this and other traits. For example, in Holstein cows of Italian breeding, a high positive relationship was found between this trait with angularity $(\mathrm{r}=0.650)$ and moderate with milk yield $(\mathrm{r}=$ 0.238) (Battagin et al., 2013). Easy and confident locomotion of cow largely depended on the condition of other descriptive traits of legs. Zavadilová et al. (2011) found that between the estimation of motion and hock angle, correlation coefficients varied from 0.33 to 0.78 , and foot angle - from 0.58 to 0.96 .

About the relationship of locomotion estimation with the assessment of angle of hock and hooves was confirmed by our studies (Fig. 4). Similarly, cows with an estimate of 9 score were used on 777 days $(\mathrm{P}<0.001)$ longer compared to animals with an estimate in 1 score.

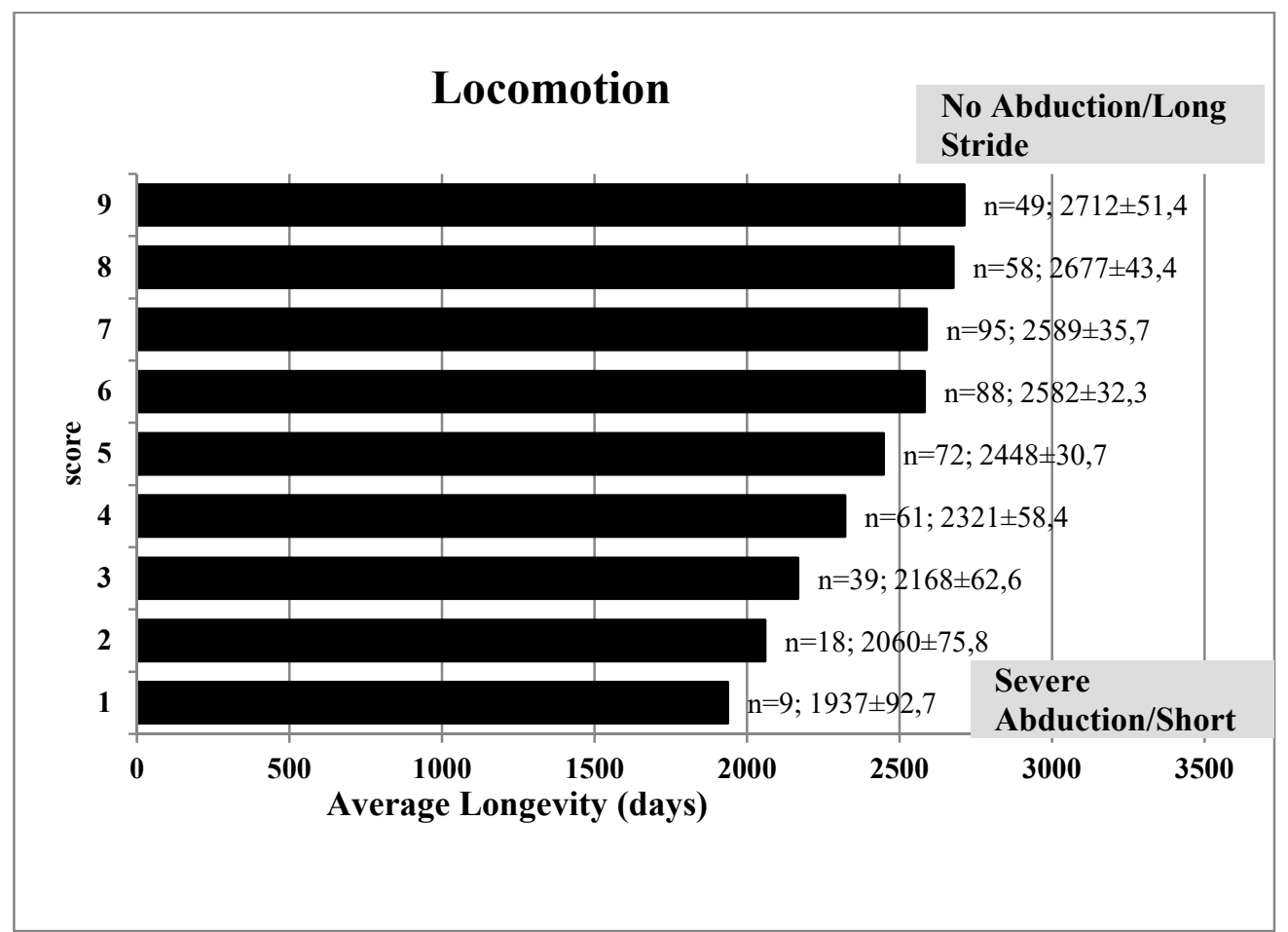

Figure 4. The influence of linear trait of locomotion on cow lifetime.

In general, when we calculated the average longevity of cows Ukrainian Brown dairy breed, depending on the score level for locomotion according to the histogram, we observed that the most enduring were cows with an estimate in 5 scores and higher.

The relationship of linear traits that characterize the development of legs of animals with the lifetime of cows confirming the positive correlation coefficients (Table 2). The greatest influence on the lifetime of cows of Ukrainian brown dairy breed has the trait of locomotion.
Table 2. Phenotypic correlation between the linear type traits that characterize the condition of legs and lifetime of cows $(n=428)$.

\begin{tabular}{lc}
\hline \multicolumn{1}{c}{ Linear type traits } & r \pm S.E. \\
\hline Rear Legs Set (side view) & $0,185 \pm 0,0524^{* * *}$ \\
Rear Legs (rear view) & $0,268 \pm 0,0471^{* * *}$ \\
Hooves Angle & $0,265 \pm 0,0587^{* * *}$ \\
Locomotion & $0,311 \pm 0,0522^{* * *}$ \\
\hline
\end{tabular}


Conclusions: The phenotypic association between linear type traits characterizing the condition of limbs and the life expectancy has been allowed to indirectly selection cows of Ukrainian Brown dairy breed by type. The rear legs (side view), rear legs (rear view), foot angle and locomotion can be predictors of longevity for dairy cattle.

Acknowledgments: This article is prepared within the framework of the grant «Justification of the methodology of preserving the brown cattle population in the conditions of the north-eastern region of Ukraine» (No0117U004253).

\section{REFERENCES}

Battagin, M., C. Sartori, S. Biffani, M. Penasa, and M. Cassandro, (2013). Genetic parameters for body condition score, locomotion, angularity, and production traits in Italian Holstein cattle. J. Dairy Science, 96(8): 5344-5351.

Boelling, D., and G. E. Pollott, (1998). Locomotion, lameness, hoof and leg traits in cattle II: Genetic relationships and breeding values. Livestock Production Science, 6: 205-215.

Buenger, A., V. Ducrocq, and H.H. Swalve, (2001). Analysis of survival in dairy cows with supplementary data on type scores and housing systems from a region of Northwest Germany. J. Dairy Science, 84: 1531-1541.

Caraviello, D. Z., K. A. Weigel, and D. Gianola, (2004). Analysis of the relationship between type traits and functional survival in US Holstein cattle using a Weibull proportional hazards model. J. Dairy Science, 87: 2677-2686.

De Haas, Y., L. L. L. Janss, and H. N. Kadarmideen, (2007). Genetic and phenotypic parameters for conformation and yield traits in three Swiss dairy cattle breeds. J. Anim. Breeding and Genetics, 124: 12-19.

Du Toit, J., J. B. van Wyk, and A. Maiwashe (2012). Relationships between functional herd life and conformation traits in the South African Jersey breed. South African J. Anim. Science, 42(1): 47-54.

Essl, A. (1998). Longevity in dairy cattle breeding: a review. Livestock Production Science, 57: 7989.

Esteves, A. M., J. A. G. Bergmann, M. C. Durães, C. N. Costa, and H. M. Silva, (2004). Genetic and phenotypic correlations between type traits and milk production in Holstein cattle. Arquivo Brasileiro de Medicina Veterinária e Zootecnia, 56: 529-535.

Getu, A., and G. Misganaw, (2015). The role of conformational traits on Dairy cattle production and their longevities. Open Access Library J., 2: e1342.

ICAR Recording Guidelines approved by the General Assembly held in Berlin, Germany, on May 2014. Copyright: 2014, ICAR. 618.

Jovanovac, S., and N. Raguž, (2011). Analysis of the relationships between type traits and longevity in Croatian Simmental cattle using survival analysis. Agriculturae Conspectus Scientificus, 76(3): 249-253.

Kern, E. L., J. A. Cobuci, C. N. Costa, C. M. McManus, and J. B. Neto, (2015). Genetic association between longevity and linear type traits of Holstein cows. J. Agricultural Science, 72(3): 203-209.

Krejcova, H., J. Priby, and V. Cermak, (2008). Estimate of breeding value for longevity in dairy cattle. J. Agrobiology, 25: 9-11.

Morek-Kopec, M., and A. Zarnecki, (2012). Relationship between conformation traits and longevity in Polish Holstein Friesian cattle. Livestock Science, 149: 53-61.

Ghaderi-Zefrehei, M., E. Rabbanikhah, H. Baneh, O. Sunday, P. Ikhide, and G. Imumorin, (2017). Analysis of culling records and estimation of genetic parameters for longevity and some production traits in Holstein dairy cattle. J. Applied Animal Research, 45(1): 524-528.

Olechnowicz, J., P. Kneblewski, J. M. Jaśkowski, and J. Włodarek (2016). Effect of selected factors on longevity in cattle: a review. The J. Anim. \& Plant Sciences, 26(6): 1533-1541.

Pfeiffer, C., B. Fuerst-Waltl, V. Ducrocq, and C. Fuerst, (2014). Approximate multivariate genetic evaluation of functional longevity and type traits in Austrian Fleckvieh cattle. In: Proc. of the 10th World Congress on Genetics Applied to Livestock Production: 17-22 August 2014; Vancouver.

Samore, A. B., R. Rizzi, A. Rossoni, and A. Bagnato, (2010). Genetic parameters for functional longevity, type traits, somatic cell scores, milk flow and production in the Italian Brown Swiss. Italian J. Anim. Science, 9: 145-152.

Sewalem, A., G. J. Kistemaker, and B. J. Van Doormaal, (2005). Relationship between type traits and longevity in Canadian Jerseys and Ayrshires using a Weibull Proportional Hazards Model. J. Dairy Science, 88: 1552-1560.

Stanojevic, D., R. Dedovic, V. Bogdanovic, N. Raguz, M. Popovac, D. Jankovic, and L. Strbac, (2016). Evaluation of the heritability coefficients of longevity in the population of Black and White cows in Serbia, Heritability 
coefficients of longevity in the population of cows, Mljekarstvo, 66(4): 322-329.

Strapak, P., P. Juhas, E. Strapakova, and M. Halo, (2010). Relation of the length of productive life and the body conformation traits in Slovak Simmental breed. Archives Animal Breeding Archiv Tierzucht, 53: 393-402.

Vacek, M., M. Stipkova, E. Nemcova, and J. Bouska, (2006). Relationships between conformation traits and longevity of Holstein cows in the Czech Republic. Czech J. Anim. Science, 51: 327-333.

Van Pelt, M. L., T. H. Meuwissen, G. de Jong, and R. F. Veerkamp, (2015). Genetic analysis of longevity in Dutch dairy cattle using random regression. J. Dairy Science, 98(6): 4117-4130.

VanRaden, P. M., and G. R. Wiggans, (1995). Productive life evaluations: Calculations, accuracy, and economic value. J. Dairy Science, 78: 631-638.

Vukasinovic, N., Y. Schleppi, and N. Kunzi, (2002). Using conformation traits to improve reliability of genetic evaluation for herd life based on survival analysis. J. Dairy Science, 85: 1556-1562.

Wiggans, G. R., L. M. Thornton, R. R. Neitzel, and N. Gengler, (2006). Genetic parameters and evaluation of rear legs (rear view) for Brown Swiss and Guernseys. J. Dairy Science, 89(12): 476-484.

Zavadilova, L., and M. Stipkova, (2012). Genetic correlations between longevity and conformation traits in the Czech Holstein population. Czech J. Anim. Science, 57(3): 125-136.

Zavadilova, L., E. Nemcova, and M. Stipkova, (2011). Effect of type traits on functional longevity of Czech Holstein cows estimated from a Cox proportional hazards model. J. Dairy Science, 94(8): 4090-4099.

Zavadilova, L., E. Nemcova, and M. Stipkova, (2009). Bouska Relationships between longevity and conformation traits in Czech Fleckvieh cows. Czech J. Anim. Science, 54(9): 387-394. 